\title{
Exploration of Banana Based Cropping System in District Khairpur Sindh Pakistan
}

\author{
Ghulam Nabi ${ }^{1} \quad$ Basit Ali Talpur $^{2} \quad$ Imran Ali Jarwar $^{1 *} \quad$ Mehrunisa Sial $^{1}$ \\ Abdul Nasir Nangraj ${ }^{1} \quad$ Aamir $^{6}$ Tahmeena Solangi $^{1}$ \\ 1.Department of Agricultural Economics, Sindh Agriculture University Tando Jam, Pakistan \\ 2. Department of Rural Development and Management, China Agriculture Univerity Bejing
}

\begin{abstract}
The climate and soil of Sindh province are favourable for cultivation of year-round for fruits. Banana is a yearround crop which is valued for energy, vitamin and mineral contents. The present study aimed to determine the socio economic status of banana growers and exploration of Banana based cropping system in district Khairpur Sindh province, by using primary data. The area and production of banana fruit is high as compare to the others provinces. In Sindh province there are three district which are contributing in the banana production likewise; Khaipur, Thatta, and Matiari, while Khairpur share in 25.9 percent area and 28.4 percent production in overall Sindh province. Banana is extremely labour intensive fruit crop by doing so huge employment opportunities to the local peoples can be provided. The banana orchard has the significant place in area allocation by the respondent's growers as banana orchard contributed 5.4 acres per household which remained 31 percent of the operational area. The Rabi season overall 48 percent operational area remained under wheat. So if we can improve our practices then we can increase the production of banana fruit.
\end{abstract}

Keywords: Banana, Based, Cropping pattern, socioeconomics, Income, Sindh

DOI: $10.7176 / \mathrm{JAAS} / 62-01$

Publication date:March $31^{\text {st }} 2020$

\section{Introduction}

Banana (Musa paradica L.) belong to the banana family Musaceae Banana, one of the most important horticultural crop and oldest fruits of the tropical area of the world. The banana is a perennial plant that replaces itself. Banana do not grow from a seed but from a bulb or rhizome. The time between planting a banana plant and the harvest of the banana bunches from 9 to 12 months of plantation. The space between the young plants especially during the first few months of crop growth, provides a scope for temporal and spatial complementarily by growing short duration, early maturing winter cash crops (Shil and Mondal 1990). However, because of different characteristics, the edible Banana is called "dessert banana" while plantain is called "cooking banana" because it is inconvenient to eat without cooking. Banana is a highly nutritious fruit which is particularly rich in easily digestible carbohydrates, dietary fibre and minerals especially potassium, magnesium and manganese. (Banana is currently the fourth largest fruit crop in the world, the Banana are grown in more than 150 countries producing 105 billion tonnes of fruit per year. World statistics show that India led the world in Banana production in 2013 producing around 20percent of the worldwide crop of 145 million tonnes. Uganda was the next largest producer with around 8 percent of the worldwide crop. Today, Banana is the premier fruit of Asia and the Pacific. It is one of the most cultivated fruits in Indonesia, Thailand, Vietnam, Philippines, Bangladesh, the South Pacific Island countries, India and Pakistan. Banana also occupies an important position in the agricultural economy of Australia, Malaysia, Taiwan, Sri Lanka, and Southern China (FAO, 2013). Banana is a major fruit crop of Pakistan. It is grown on 34,800 hectares with production of 154,800 tons. Sindh province of Pakistan has the major share with 87percent of total area followed by KPK, Punjab and Baluchistan. The banana crop in Sindh was approached 32,200 hectares with production of 127,400 tons with 87percent share of banana production in the country (GOP 2014) and the northern parts of Sindh particularly district Khairpur with the total area 5121 hectares with 25.9 percent hectare khairpur district total share in Sindh 21563 tonnes with 28.4percent in year (GOP, 2011-12). It is mainly grown in Sindh province where the soil and climatic conditions are miracle for its successful cultivation. The total share of Sindh province alone in its cultivation is 87 percent with the total share of Sindh province is 89percent in total production. Major banana producing districts in Sindh are Khairpur, Matiari. The leading banana producing districts of Sindh province are Khairpur, Thatta, and Hyderabad with production of 35,324, 30,432, and 21,996 tons respectively (GOP, 2014).

About 300 varieties of bananas are grown, of which a vast majority are grown in tropical Asia (Simmonds, 1962). Ninety-five per cent of area is under Basrai variety (Cavendish dwarf), whereas remaining under William Hybrid. Recent introductions include variety Grand Nine (G-9) while the work is underway to introduce high yielding Chinese varieties viz. B-10, W-11, and Pashing. The majority of banana producers were 88.33 percent of Basrai (Cavendish dwarf) verity cultivate, while 6.66 percent respondent were cultivating William (Hybrid) verity, 1.66 percent Grand Nine (G-9), 1.66 percent B- 10 (Hybrid) and 2.58 percent W-11 (Hybrid) verity were cultivated. The most commonly known banana is the Cavendish variety, which is the one produced for export markets. A 
new strain of Panama disease, the fungus that wiped out the Gross Michel variety in the 1950s, has hit the world's biggest export banana, Cavendish. If left unchecked it could wipe out the cultivar due to Cavendish variety also disease free variety, all varieties of banana can be used for the fibre extraction purpose (Mukhopadhay et al., 2008).

\section{Objectives}

1. To examine the socio economics characteristics of the farmers

2. To explore the status of cropping pattern in study area

3. To examine the farm characteristics

\section{Review of literature}

Memon, et al., (2016), reported that Agricultural sector of Pakistan is usually divided into four main sub-sectors: crops, livestock and forestry and fisheries, Banana is an important sector of Pakistan. But banana growers are facing problems because majority of growers uneducated they cannot use technology proper and same Banana sector of Pakistan is facing serious problems from production to post harvest management and export marketing. In view of limited awareness due to uneducated farmers and labour in this sector. Untrained farmers and labour in this sector. Lack of Proper information about pre and post-harvest management. And not available testing laboratories in Sindh, this sector related to middlemen and contractors he also lacks of knowledge, lack of storage facilities infrastructure problems of transports.

Mondragon et al., (2015), reported that infertile soil or soil with too little nutrition lowered banana yields since bananas could not get enough nutrition. Seed germination is significantly dependent on specific environmental conditions which affect seedling establishment. Individual growth rates of seedlings are slow and limited when soil nutrients and water are inadequate. Plant growth rates finally depend on the plant's maturity.

Sopheap et al., (2012) reported that Yield is very important for farmers since it reflects their incomes. Most farmers needed high yields. They had different strategies to improve yields, such as choosing a good quality banana variety, investing in good quality fertilizers, and adopting good agricultural practices. The main yield constraints were identified as poor soil quality, harvesting at the wrong time, and poor weed management. The highest yield fields did not have these problems because those farmers had good crop management knowledge.

Javelosa and Schmitz (2006), reported that, the industry was long characterised by some form of government protection and help, such as particular railway lines facilitating transport built in the 1960s, and restrictive quarantine regulations holding for foreign imports. By the 1990s, a total import ban for all foreign bananas was in effect, with the official rationale being strict quarantine considerations, i.e. that the import of bananas might aggravate the prevalence of banana diseases in Australia. This rationale is subject of a WTO dispute between representatives of the Philippine banana growers on one hand and the Australian government on the other.

Bakhtiari et al. (2014), reported that Banana nutrition depends on the plant's growing stages, which require different amounts of fertilizer. The reproductive stage requires more potassium than nitrogen. The appropriate fertilizer rates that give nutrients at different ratios improve yields. Application time is crucial as bananas need different nutrients at different stages. Net corn yields for example, significantly increased when fertilizer rates were increased from 30 to $90 \mathrm{~kg} / \mathrm{ha}$, even though corn height and the amount of corn cobs were not significantly different. The application rate of fertilizer had a direct influence on net corn yield.

\section{Methodology}

This study was based on Primary data and collected using well-structured questionnaire from district Khairpur Sindh. Both quantitative and qualitative data were collected according to exploration of banana based cropping system in district Khairpur Sindh. It was purposely selected and banana fruit are particularly cultivated in district Khairpur. However, the information was collected from the respondent, collect/record pertaining to socioeconomic characteristics, of the banana growers, family income, land ownership pattern etc.

Analysis of data

Data were analysed to achieve the objectives of the study, farmers were divided in two categories Small (up to 12.5) and Large (12.5 above) For this study, tabular analysis was applied to classify data in order to derive meaningful findings by using simple statistical measures like percentage and ratios in SSPS and Excel software.

Percentage

It was calculated by using following formula:

Percentage $=\mathrm{F} / \mathrm{N}^{*} 100$

$\mathrm{F}=$ Sample of respondent

$\mathrm{N}=$ Total number of respondent

Average or Mean

Sum of all observation divided by total number of observation

Mean 0r $\bar{X}=\frac{\sum \mathrm{xi}}{\mathrm{n}}$ 
$\sum x i=$ sum of all observation

$\mathrm{n}=$ number of observation

\section{Standard Deviation}

A quantity expressing by how much the members of a group differ from the mean value for the group.

The sample standard deviation formula is:

$\mathrm{SD}=\sqrt{\frac{\sum(X-\bar{X})^{2}}{n-1}}$

$\mathrm{SD}=$ sample standard deviation

$\sum=$ sum of...

$\bar{X}=$ sample mean

$\mathrm{n}=$ number of observation

\section{Results}

\section{Area and Production of Pakistan}

Banana is an important fruit of Pakistan and mostly grown in Sindh provinces 91.2percent share in area and 82.1percent overall share in production. While in Punjab area was 2.5percent and share of production 5.2percent. in KPK area was 2.5percent and production 9.9percent. whenever area was 2.9percent and 2.8percent share in production. (Table 1.)

Table 1. provinces wise area and production of Pakistan "000" hec

\begin{tabular}{|c|c|c|c|c|c|}
\hline Year & Punjab & Sindh & KPK & Baluchistan & Pakistan \\
\hline $2009-10$ & 1.4 & 32.2 & 0.7 & 0.5 & 34.8 \\
\hline $2010-11$ & 1.2 & 26.8 & 0.7 & 0.9 & 29.6 \\
\hline 2011-12 & 1.1 & 19.8 & 0.7 & 0.9 & 22.5 \\
\hline $2012-13$ & 0.7 & 25.0 & 0.7 & 0.9 & 27.3 \\
\hline 2013-14 & 0.5 & 25.9 & 0.7 & 0.9 & 28.0 \\
\hline Average & 1.0 & 25.9 & 0.7 & 0.8 & 28.4 \\
\hline area in percent & 3.4 & 91.2 & 2.5 & 2.9 & 100.0 \\
\hline \multicolumn{6}{|c|}{ (Production '000' tonnes) } \\
\hline $2009-10$ & 9.4 & 127.4 & 13.2 & 4.8 & 154.8 \\
\hline $2010-11$ & 10.3 & 113.4 & 12.6 & 4.9 & 141.2 \\
\hline 2011-12 & 6.2 & 76.0 & 13.0 & 3.0 & 98.2 \\
\hline $2012-13$ & 4.3 & 121.2 & 13.1 & 2.7 & 141.3 \\
\hline $2013-14$ & 3.8 & 100.8 & 13.1 & 2.7 & 120.4 \\
\hline Average & 6.8 & 107.8 & 13.0 & 3.6 & 131.2 \\
\hline Production in percent & 5.2 & 82.1 & 9.9 & 2.8 & 100.0 \\
\hline
\end{tabular}

Source: author and analysis based on GOP data

Area and production of banana in Sindh (province)

In Sindh province Banana is predominantly grown in Khaipur, Thatta, and Matiari districts the khairpur contribute 25.9percent in area and 28.4percent in production followed by Thatta secure with 17.8percent production and matiari contribute 13.8percent the overall three district 60percent share in Sindh produce. 
Table 2. District Wise area and production of Sindh provinces of Banana 2011-12 (area in Hectares, Production in tonnes)

\begin{tabular}{|c|c|c|c|c|}
\hline Districts & Area & percent & Production & percent \\
\hline Khairpur & 5121 & 25.9 & 21563 & 28.4 \\
\hline Ghotki & 203 & 1.0 & 885 & 1.2 \\
\hline Sukkur & 107 & 0.5 & 460 & 0.6 \\
\hline N.Feroze & 1772 & 9.0 & 8022 & 10.5 \\
\hline S.B.A & 2136 & 10.8 & 8656 & 11.4 \\
\hline Jaccobabad & 0 & 0.0 & 0 & 0.0 \\
\hline Kashmore & 0 & 0.0 & 0 & 0.0 \\
\hline Shikarpur & 8 & 0.0 & 32 & 0.0 \\
\hline Larkana & 0 & 0.0 & 0 & 0.0 \\
\hline Kamber & 0 & 0.0 & 0 & 0.0 \\
\hline Sanghar & 1492 & 7.6 & 4144 & 5.4 \\
\hline Tharparkar & 0 & 0.0 & 0 & 0.0 \\
\hline Mirpurkhas & 312 & 1.6 & 583 & 0.8 \\
\hline Umerkot & 65 & 0.3 & 130 & 0.2 \\
\hline Dadu & 65 & 0.3 & 224 & 0.3 \\
\hline Jamshoro & 50 & 0.3 & 178 & 0.2 \\
\hline Hyderabad & 412 & 2.1 & 1670 & 2.2 \\
\hline Matiari & 2713 & 13.7 & 10458 & 13.8 \\
\hline Tand Allahyar & 702 & 3.6 & 2248 & 3.0 \\
\hline T.M.Khan & 537 & 2.7 & 1847 & 2.4 \\
\hline Badin & 412 & 2.1 & 1271 & 1.7 \\
\hline Thatta & 3472 & 17.6 & 13041 & 17.1 \\
\hline Karachi & 177 & 0.9 & 630 & 0.8 \\
\hline Total & 19756 & 100.0 & 76042 & 100.0 \\
\hline
\end{tabular}

Source: Authors analysis based on GOP data

Socioeconomic characteristics of banana growers

Socioeconomic status (SES) is an economic and sociological measure of a person's work experience of an individual's or family's economic and social position in relation to others, based on income, education, and occupation.

The study represents a brief description of the socio-economic characteristics of the selected banana growers. Decision making behaviour of individual is determined to a large extent by his socio-economic characteristics. The socio-economic variables of the banana growers are given below.

\section{Age, Education and Farming Experience}

The average age of small farmers was 43.5 years, and year for 39.3 large farmers. There was no significant variation in age small and large farmers in Khairpur district the overall average age of farmers was 41.4 years. Education plays a vital role in attitude formation of mind. The any activity of farming is belonging to education. Unfortunately, the result show that the literacy rate in the study area is very low. Overall average of education 6.5 years. Average farming experience of selected growers was 12.3 years of small farmers and 12.6 years of large farmers. Overall farming experience 12.5 years by the respondent farmers.

Table 3. Age, Education and Farming Experience of the respondents

\begin{tabular}{|l|r|r|r|r|r|r|}
\hline \multirow{2}{*}{ Farm category } & \multicolumn{2}{|c|}{ Small } & \multicolumn{2}{c|}{ Large } & \multicolumn{2}{c|}{ Total } \\
\cline { 2 - 7 } & \multicolumn{1}{|c|}{ Mean } & \multicolumn{1}{c|}{ S.D } & \multicolumn{1}{c|}{ Mean } & \multicolumn{1}{c|}{ S.D } & \multicolumn{1}{c|}{ Mean } & \multicolumn{1}{c|}{ S.D } \\
\hline Age (year) & 43.5 & 13.0 & 39.4 & 13.2 & 41.4 & 13.2 \\
\hline Education & 6.2 & 4.8 & 6.8 & 5.7 & 6.5 & 5.2 \\
\hline Farming Experience & 12.3 & 8.7 & 12.6 & 10.1 & 12.5 & 9.4 \\
\hline
\end{tabular}

Source: Survey data 2015

Living pattern

Regarding the living pattern of the respondent of banana growers in study area majority ( 80 percent) farmers were living in the joint-family system and 20 percent were living in single-family system. Result revealed that jointfamily system is the dominant in the study area. 
Table 4. Gender of the respondents

\begin{tabular}{|l|r|r|}
\hline & Frequency & \multicolumn{2}{|c|}{ Percent } \\
\hline Joint & 44 & 80 \\
\hline Single & 11 & 20 \\
\hline Total & 55 & 100 \\
\hline
\end{tabular}

Source: survey data 2015

\section{Land Holding}

Overall mean operational area was 17.3 acres with 5.2 acres for small and 30.2 acres for large farmers respectively. The overall average share-in area was 1.8 acres and the overall average leased-in area was 6.7 acres in the selected study area also explain cultivated and non-cultivated area.

Table 7. Land Holding

\begin{tabular}{|l|r|r|r|r|r|r|}
\hline \multirow{2}{*}{ Farm Category } & \multicolumn{2}{|c|}{ Small } & \multicolumn{2}{c|}{ Large } & \multicolumn{2}{l|}{ Total } \\
\cline { 2 - 8 } & \multicolumn{1}{|c|}{ Mean } & \multicolumn{1}{c|}{ S.D } & \multicolumn{1}{l|}{ Mean } & S.D & \multicolumn{1}{l|}{ Mean } & \multicolumn{1}{l|}{ S.D } \\
\hline Cultivated & 4.9 & 3.5 & 23.6 & 24.5 & 13.1 & 19.8 \\
\hline Non-cultivated & 0.0 & 0.2 & 2.0 & 5.1 & 1.0 & 3.7 \\
\hline Share in & 0.0 & 0.2 & 3.4 & 6.4 & 1.8 & 4.8 \\
\hline shared out & 0.0 & 0.0 & 0.3 & 1.8 & 0.1 & 1.3 \\
\hline Leased in & 0.5 & 1.4 & 4.5 & 9.0 & 2.5 & 6.7 \\
\hline Leased out & 0.2 & 0.8 & 1.1 & 4.0 & 0.7 & 2.9 \\
\hline Operational Holding & 5.2 & 3.4 & 30.2 & 22.0 & 17.3 & 20.2 \\
\hline
\end{tabular}

Source: survey data 2015

Family size and farm workers

Overall average family Size was 19 persons per household whereas small farmers have 13 and large farmer have 24 family member in the study area. Overall family farm worker's male was 3 persons, whereas small farmers have 1.8 and large farmer have 4.0 family farm worker's male in the study area. There was about 1 non-farm working male having income PRs 9390.9 per month. Family farm work female about 0.5 per household.

Table 5. Family size and Farm workers

\begin{tabular}{|l|r|r|r|r|r|r|}
\hline \multicolumn{1}{|c|}{ Farm category } & \multicolumn{2}{c|}{ Small } & \multicolumn{2}{c|}{ Large } & \multicolumn{1}{c|}{ Total } \\
\hline & \multicolumn{1}{c|}{ Mean } & \multicolumn{1}{c|}{ S.D } & \multicolumn{1}{c|}{ Mean } & \multicolumn{1}{c|}{ S.D } & \multicolumn{1}{c|}{ Mean } & \multicolumn{1}{c|}{ S.D } \\
\hline Family Size & 13.0 & 8.7 & 24.1 & 13.6 & 18.6 & 12.6 \\
\hline Family Farm Workers(male) & 1.8 & 1.2 & 4.0 & 2.24 & 3 & 2.1 \\
\hline Family farm work (female) & 0.8 & 1.5 & 0.2 & 1.05 & 0.5 & 1.3 \\
\hline Working non-farm (male) & 0.9 & 1.0 & 0.9 & 1.56 & 0.9 & 1.3 \\
\hline Working non-Farm (female) & 0.0 & 0.1 & 0 & 0 & 0.0 & 0.1 \\
\hline male non-farm work PKR/m & 10129.6 & 10819.8 & 8678.5 & 16002.4 & 9390.9 & 13599.3 \\
\hline female non-farm income PKR./m & 0 & 0 & 0 & 0 & 0 & 0 \\
\hline Pension anybody retired PKR./m & 0 & 0 & 0.0 & 0.2 & 0.0 & 0.1 \\
\hline Other income (rent etc. PKR./m & 0 & 0 & 500 & 1855.9 & 254.5 & 1336.3 \\
\hline
\end{tabular}

Source: Survey data 2015

\section{Household income}

Overall the banana contribution in household income 40percent of the household followed by crops 29percent and livestock 12percent, and non-farm 19percent for small and large respectively.

Table 6. Different sources of household income (percent)

\begin{tabular}{|l|l|r|r|r|r|}
\hline Farm category & banana & Intercropping & \multicolumn{1}{c|}{ livestock } & off-farm \\
\hline \multirow{3}{*}{ Small } & Mean & 40.19 & 21.48 & 3.04 & 20.48 \\
\cline { 2 - 6 } & Std. Deviation & 30.33 & 19.94 & 5.02 & 27.23 \\
\hline \multirow{2}{*}{ Large } & Mean & 28.32 & 16.79 & 5.64 & 11.39 \\
\cline { 2 - 6 } & Std. Deviation & 26.44 & 20.09 & 9.98 & 17.75 \\
\hline \multirow{2}{*}{ Total } & Mean & 39.15 & 29.27 & 12.36 & 18.85 \\
\cline { 2 - 6 } & Std. Deviation & 28.78 & 26.53 & 7.98 & 23.14 \\
\hline
\end{tabular}

Source: survey data 2015

\section{Rabi Season cropping system}

Result of cropping structure revealed that in the rabi season, wheat was the major crop with overall 48 percent operational area. However, 22 percent small and 52 percent large farmer's operational area remained under wheat. The banana orchard has the significant place in the area allocation by the respondent farmers with overall respondent 31 percent of operational holding. Small farmers allocated 53.4percent of operational holding to banana orchard for their livelihood whereas large farmers have 27.1percent banana orchard. 
Table 8. Rabi cropping pattern

\begin{tabular}{|l|r|r|r|r|r|r|}
\hline \multicolumn{1}{|c|}{ Farm category } & \multicolumn{2}{|c|}{ Small } & \multicolumn{2}{c|}{ Large } & \multicolumn{2}{c|}{ Total } \\
\hline Characteristics & \multicolumn{1}{|c|}{ Mean } & Operation \% & \multicolumn{1}{c|}{ Mean } & Operation \% & \multicolumn{1}{c|}{ Mean } & Operation \% \\
\hline Wheat & 1.1 & 22.3 & 15.2 & 52.3 & 8.3 & 47.9 \\
\hline Fodder & 0.1 & 2.5 & 0.4 & 1.3 & 0.3 & 1.5 \\
\hline Sugarcane & 0.3 & 5.7 & 0.8 & 2.8 & 0.6 & 3.3 \\
\hline Lemon & 0.0 & 0.0 & 0.3 & 0.9 & 0.1 & 0.7 \\
\hline Other Crops & 0.0 & 0.0 & 0.4 & 1.2 & 0.2 & 1.0 \\
\hline Vegetables & 0.0 & 0.7 & 0.6 & 2.2 & 0.3 & 2.0 \\
\hline Fallow & 0.2 & 3.3 & 0.2 & 0.6 & 0.2 & 1.0 \\
\hline Banana Orchard & $\mathbf{2 . 8}$ & $\mathbf{5 3 . 4}$ & $\mathbf{7 . 9}$ & $\mathbf{2 7 . 1}$ & $\mathbf{5 . 4}$ & $\mathbf{3 1 . 0}$ \\
\hline Dates Orchard & 0.3 & 6.6 & 2.2 & 7.7 & 1.3 & 7.5 \\
\hline Mango Orchard & 0.3 & 5.4 & 1.1 & 3.9 & 0.7 & 4.1 \\
\hline Operational & 5.2 & 100.0 & 29.0 & 100.0 & 17.3 & 100.0 \\
\hline
\end{tabular}

Source: survey data 2015

\section{Kharif season cropping pattern}

In Kharif season banana orchard has the first place as 5.4 acres with 30 percent share of land is being allocated for the banana orchard. Cotton remained major Kharif crop by the survey respondent with 12 percent, and the overall others crops of Kharif season 27 percent operational holding

Table 9. Cropping pattern in kharif season

\begin{tabular}{|l|r|r|r|r|r|r|}
\hline Farm Categories & \multicolumn{2}{|c|}{ Small } & \multicolumn{2}{|c|}{ Large } & \multicolumn{2}{c|}{ Total } \\
\hline Characteristics & Mean & percent of opera & Mean & percent of opera & Mean & percent of opera \\
\hline Rice & 0.3 & 5.8 & 1.6 & 5.5 & 1 & 5.5 \\
\hline Fodder & 0.3 & 5 & 0.6 & 2.2 & 0.4 & 2.6 \\
\hline Cotton & 0.6 & 11.5 & 8.1 & 27.9 & 2.1 & 12.2 \\
\hline Vegetables & 0.1 & 1.4 & 0.5 & 1.7 & 0.3 & 1.7 \\
\hline Other crops & 0 & 0 & 4.7 & 16.2 & 4.7 & 27.1 \\
\hline Sugarcane & 0.3 & 5.5 & 1.2 & 4.1 & 0.7 & 4.3 \\
\hline Lemon & 0.3 & 5.7 & 0.8 & 2.8 & 0.6 & 3.3 \\
\hline Dates orchard & 0 & 0 & 0.3 & 0.9 & 0.1 & 0.7 \\
\hline Banana orchard & 2.8 & 53.4 & 7.9 & 27.1 & 5.4 & 31 \\
\hline Mango orchard & 0.3 & 6.6 & 2.2 & 7.7 & 1.3 & 7.5 \\
\hline Fallow area & 0.3 & 5.4 & 1.1 & 3.9 & 0.7 & 4.1 \\
\hline Operational & 5.2 & 100 & 29 & 100 & 17.3 & 100 \\
\hline
\end{tabular}

Source: survey data 2015

\section{Conclusions}

The area and production of banana fruit is high as compare to the others provinces. In Sindh province there are three district which are contributing in the banana production likewise; Khaipur, Thatta, and Matiari, while Khairpur share in 25.9 percent area and 28.4 percent production in overall Sindh province. Banana is extremely labour intensive fruit crop by doing so huge employment opportunities to the local peoples can be provided. The banana orchard has the significant place in area allocation by the respondent's growers as banana orchard contributed 5.4 acres per household which remained 31 percent of the operational area. The Rabi season overall 48 percent operational area remained under wheat. So if we can improve our practices then we can increase the production of banana fruit.

\section{References}

Banana Market- Review and Banana Statistics- 2012-13, FAO Faostal Database, United Nation

Bakhtiari, M., Ghahraei, O., Ahmad, D., Yazdanpanah, A., \& Jafari, MA. (2014). Selection of fertilization method and fertilizer application rate on corn yield. Agricultural Engineering International: CIGR Journal, 16(2), 10-14.

Dale JL, D Becker, P Beetham, T Burns, B Dugdale, C Horser, M Karan, R Wanitchakorn and R Harding, 1998. Genome organization of banana bunchy top virus. Abstract: 2nd Int.

Workshop on Bemisia and Geminiviral diseases, June 7-12, 1998, San Juan, Puerto Rico. L-86

GOP, 2014. Government Pakistan, Economic Survey of Pakistan, Economic Advisory wing, Finance Division

Javelosa, J \& Schmitz, A 2006, 'Costs and Benefits of a WTO Dispute: Philippine Bananas and the Australian Market', Estey Centre Journal of International Law and Trade Policy, 7, pp. 58-83.

Ministry of National Food Security and Research, Islamabad 
Mondragon, D., Valverde, T., \& Hernandez-Apolinar, M. (2015). Population ecology of epiphytic angiosperms: A review. Tropical Ecology, 56(1), 1-39.

Mukhopadhyay, S., Fangueiro, R., Yusuf, A. and Senturk, U. 2008. Banana fibresvariability and fracture behaviour. Journal Engineered Fibres and Fabrics, 3(2): 39- 45.

Memon, I. N, H. Wagan, S. Noonrani, 2016 'Economic Analysis Of Banana Production Under Contract Farming In Sindh Pakistan, Journal Of Marketing And Consumer Research Www.Iiste.Org Issn 2422-8451 An International Peer-Reviewed journal

Pakistan Bureau of Statistics, Government of Pakistan

Rane, A.A. and Bagade, S.R., 2006, Economics of production and marketing of banana in Sindhudurg district, Maharashtra. Ind. J. Agric. Econ., 20 (1): 38-45.

Shil NC and Mondal MF (1990). Intercropping in Banana with Some Short Duration Crops Bangladesh Journal of Extension 5(1\&2): 75-80

Sopheap, U., Patanothai, A., \& Aye, TM. (2012). Unveiling constraints to cassava production in Cambodia: An analysis from farmers' yield variations. International Journal of Plant Production, 6(4), 409-427.

Simmonds, N. W. 1962. The evaluation of bananas. Tropical Science Series (Longmans, London).

SEDF,2014.http://sedf.gos.pk/pdf/sectors/banana/Anpercent20overviewpercent20ofpercent20bananapercent20pr oductionpercent20Sindh.

Trade Development Authority of Pakistan

Turner DW, Lahav E, 1983. The growth of banana plants in relation to temperature. Australian Journal of Plant Physiology 10:43-54. 